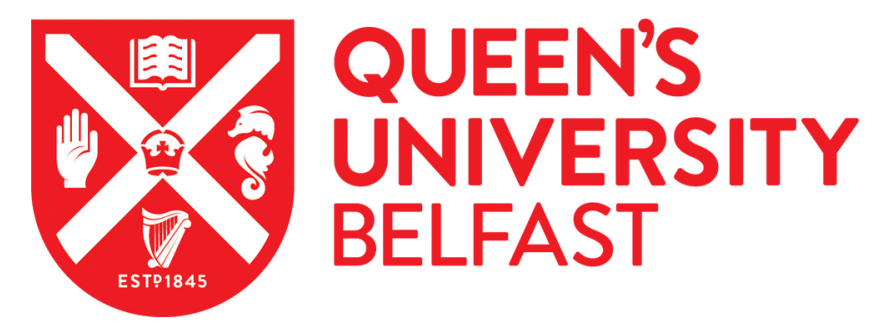

\title{
Contested landscapes: the moral geographies of light pollution in Britain
}

Dunnett, O. (2015). Contested landscapes: the moral geographies of light pollution in Britain. Cultural Geographies, 22(4), 619-636. https://doi.org/10.1177/1474474014542746

\author{
Published in: \\ Cultural Geographies
}

\section{Document Version:}

Peer reviewed version

Queen's University Belfast - Research Portal:

Link to publication record in Queen's University Belfast Research Portal

Publisher rights

Copyright the author

\section{General rights}

Copyright for the publications made accessible via the Queen's University Belfast Research Portal is retained by the author(s) and / or other copyright owners and it is a condition of accessing these publications that users recognise and abide by the legal requirements associated with these rights.

Take down policy

The Research Portal is Queen's institutional repository that provides access to Queen's research output. Every effort has been made to ensure that content in the Research Portal does not infringe any person's rights, or applicable UK laws. If you discover content in the Research Portal that you believe breaches copyright or violates any law, please contact openaccess@qub.ac.uk. 


\section{Contested Landscapes: The Moral Geographies of Light Pollution in Britain}

\section{Oliver Dunnett, Queen's University Belfast}

Post-print version of article submitted to cultural geographies

\section{Introduction}

Light pollution is a term that has entered the popular imagination in recent years, and although the precise origins of the phrase remain uncertain, it is likely to have emerged alongside the establishment of dark-sky lobby groups in the late-20 ${ }^{\text {th }}$ century, including the UK's Campaign for Dark Skies (est. 1990), which is the main empirical focus of this paper. From an astronomical perspective, light pollution has been defined as 'the veiling effect upon celestial objects of light emitted with an upward component from local or distant luminaires' ${ }^{11}$. In a more general sense, however, light pollution has been identified as 'artificial light that is excessive or intrudes where it is not wanted'2, and is said to occur 'when artificial outdoor lighting becomes inefficient, annoying and unnecessary'3. Associated with the 'dark skies' lobby in Britain and the United States has been a range of terminology that is used to describe different types of light pollution. Firstly, we have the term 'skyglow', defined as light which is 'projected from the ground ... colouring the night sky and reducing the visibility of astronomical objects'4. Furthermore, 'glare' is a more common term denoting lights that are over-bright and poorly directed, so as to obscure rather than illuminate its subject. Related to this is 'light trespass' or 'light nuisance', where a specific light is deemed to have over-reached its intended purpose, either in direction or intensity ${ }^{5}$. In all cases, the perceived problems of light pollution constitute an essentially spatial concern - of light that 'belongs' in one place but is seen as 'out of place' when it transgresses in certain ways ${ }^{6}$. As such, this paper's aims are twofold: firstly, to provide a geographical understanding of light pollution and the campaign against it in Britain, and, second, to make contributions to a new area of research, the geographies of light and darkness. In doing this, the paper focuses on the register of landscape, which is often presented as a site of contestation in light pollution debates, and whose multiple scholarly interpretations can form a useful means of understanding light pollution's contrasting regimes of vision and experience.

\section{The Campaign for Dark Skies}

The anti-light-pollution lobby in Britain is chiefly composed of the Campaign for Dark Skies (CfDS), which was established as a branch of the British Astronomical Association (BAA), the UK's principal amateur organisation for astronomers. It was formed with support from the Campaign to Protect Rural England (CPRE), which has its own interest in countering the effects of light pollution as part of its rural preservationist agenda. Although instances of light pollution have been documented before this period, the CfDS was the first co-ordinated campaign against light pollution in Britain. Looking further back, however, additional context for the BAA's campaign can be found around the time of the group's origins in the late-19 ${ }^{\text {th }}$ century. During this period, the quest for optimal viewing conditions commonly took astronomers away from the unreliable climatic conditions of the British Isles on lengthy expeditions to locations including the Portuguese island of Madeira, where BAA founder member Nathaniel Green made a successful series of observations of the planet Mars in $1877^{7}$. Such expeditions highlight the almost obsessive preoccupation with clear viewing conditions that has characterised the practise of amateur astronomy, and it could be argued that the modern day CfDS in part represents an extension of this concern. 
There are, however, a more specific set of concerns that prompted the initiation of the Campaign in the late-1980s. Coinciding with heightened concerns about global atmospheric pollution as part of the broader environmental movement of the late- $20^{\text {th }}$ century ${ }^{8}$, astronomers around this time became increasingly aware that 'the night sky was beginning to disappear' ${ }^{9}$. To this effect, what was a gradual process of increased artificial lighting across Britain seemed to have reached a biting point, propelled by the introduction of new types of sodium light fittings ${ }^{10}$. These concerns were raised in BAA Council meetings, and in February 1990 it was decided that a committee should be formed to discuss the issue and propose ways to 'ameliorate not only the astronomical nuisance but also the energy pollution caused by street and other public artificial lighting ${ }^{11}$. This committee subsequently became one of several established 'sections' of the BAA in May 1990 as the Campaign for Dark Skies, with a modest budget of around $£ 1000$ per year ${ }^{12}$. It should be emphasised that, although the CfDS emerged from the growing frustration that amateur astronomers experienced at the interference of artificial light with their observations of celestial bodies in the night sky, the Campaign now lobbies against light pollution as a problem which affects all people in the developed world, not just astronomers. As such, as well as its stated goal of 'winning back the wonders of the night sky'13, the anti-light-pollution lobby is keen to highlight related social issues such as perceptions of crime, energy efficiency and public safety ${ }^{14}$, whilst also emphasising the emerging evidence of harm that excessive artificial light is reported to have on human health ${ }^{15}$, and its adverse effects on nocturnal fauna and invertebrates ${ }^{16}$.

Here, a note about the scope of the paper, and the wider structures of the light pollution lobby, is required. In Britain, the BAA and the CPRE represent the principal organisations involved, whilst the UK's pre-eminent group for professional astronomers, the Royal Astronomical Society, takes little official interest in light pollution, an absence which has been attributed to their wide-ranging commitments to observatories, funding of astronomical research and education ${ }^{17}$. It does appear as though light pollution is therefore primarily an amateur concern within the astronomy community, which may reflect the fact that amateurs are more likely to observe the night sky from their own properties or in public spaces, rather than from well-positioned, high-specification observatories that would be better able to militate against the interference of light pollution. Other types of organisation have also been noted to have an interest in light pollution, including the invertebrate conservation charity Bug Life, whilst other groups are known to have been set up since the early1990s, but were either absorbed into the CfDS or fell by the wayside, such as the group 'Dark Skies $2000^{\prime 18}$. At a broader scale, the International Dark Sky Association operates in the United States, working with national groups and promoting 'Dark Sky Places' worldwide ${ }^{19}$. This paper, however, focuses on the UK, and, following a short discussion of literature on the topics of light, darkness and moral geographies of landscape, the Campaign for Dark Skies is presented as a group whose goals are essentially geographical in nature. Drawing on in-depth interviews with three key members of the Campaign, past and present ${ }^{20}$, as well as textual analysis of promotional material and consultation of institutional archives, the article goes on to highlight two connected themes that are deemed to characterise the anti-light-pollution lobby in Britain. These are, 1) the elucidation of sublime representations and experiences of landscape as a means of framing what is at risk in the eyes of anti-light-pollution campaigners, and 2) the underlying geographical discourse of urbanisation and the threat this is seen to pose to dark night skies, as constructed through the additional scopic regime of satellite imagery. The paper does not seek to examine the views of the general public, focusing as it does on the most active proponents of light pollution reduction, nor 
does it offer any detailed views on the relative success of the Campaign, beyond its own claims, and its limited impact on the UK lighting industry.

\section{Enlightenment, Morality and Landscapes of Light and Dark}

A number of accounts have been written on histories of artificial lighting, which usefully explore the meaning of light in the modern age, often drawing parallels between the advent of artificial lighting and the onset of the Enlightenment in Europe. Indeed, Wolfgang Schivelbusch suggests that 'perhaps ... the philosophical need for enlightenment awakened an interest in real light' ${ }^{21}$, and situates the emergence of artificial light in the context of 'the flame cultivated for light thousands of years ago [which] remained essentially unchanged until the $18^{\text {th }}$ century ${ }^{\prime 22}$. Schivelbusch goes on to document the 'modernisation of the flame' through the introduction of gas lighting in $18^{\text {th }}$ century France and Britain, attributing its initial development to the need for industrial lighting, and then charting the emergence of pioneering lighting companies such as Watt and Boulton in the English West Midlands. As well as its effect on extending the night time industrial economy, the propagation of artificial lighting is said to have contributed to the nocturnalisation of urban social and cultural practices in this period, both in Europe ${ }^{23}$ and the Unites States ${ }^{24}$, as demonstrated through such examples as the brightly lit amusement boulevards of $19^{\text {th }}$ century Paris ${ }^{25}$, and illuminated night walks at Vauxhall Pleasure Gardens in $19^{\text {th }}$ century London ${ }^{26}$. This illumination of outdoor spaces at night was, of course, paralleled by the development of domestic gas lighting, whose associated technologies developed during the Victorian era with increasing standards of control, metering and regulation ${ }^{27}$. Accelerating this expansion of artificial illumination, the late- $19^{\text {th }}$ century saw the introduction of electric lighting, which was celebrated at events such as the Paris Electricity Expo in 1881, and Berlin's Festival of Light in 1928. Indeed, this new, cleaner form of lighting was representative of widespread acclaim for the wonders of electricity in the late- $19^{\text {th }}$ and early- $20^{\text {th }}$ centuries, even to the extent that it was 'regarded as positively beneficial, almost as a sort of vitamin ${ }^{\prime 28}$.

Alongside such narratives of progress in lighting and enlightenment, a reciprocal view of darkness representing backwardness and atavistic regression has been explored. As such, Chris Otter has noted how, in Victorian England, darkness in urban areas was seen to generate 'sickness, depravity and lassitude ${ }^{29}$, whilst in the 'gaslight era' of the United States, Peter Baldwin has identified tangible fears among the urban middle-classes that, in the event of blackouts, 'the order of the modern city would be snuffed out in an upheaval of hitherto supressed social animosities and amoral impulses' ${ }^{30}$. Furthermore, Tim Edensor has highlighted how 'longstanding fears [of darkness] have origins in the very real perils that pervaded a pre-illuminated world after nightfall' ${ }^{31}$, but are nevertheless presented against symbolic invocations of light as a metaphor for truth, reason and divinity in the Western world. Such representations can be seen in accounts of European explorers of the time, who were often portrayed bathed in white light, in contrast to the darkness that characterised their non-European surroundings $\mathrm{s}^{32}$. These examples help show how the idea of light, both in a practical and symbolic sense, has come to be associated with modernisation and the so-called 'Enlightenment project' in various different ways, encompassing domestic, economic and public spaces. Here we can also see how the metaphor of light has taken on a moralising tone, seen as an all-encompassing force for good, banishing the ignorance of darkness in modern society ${ }^{33}$. 
However, this binary narrative of light and dark has not gone unchallenged. Indeed, whilst the advent of artificial lighting was widely accepted as a positive development, there have been instances where lighting has been seen as undesirable, even to the point of violent protest, most notably during the French Revolution in the act of 'lantern smashing' by those who sought to subvert the power over public areas that was expressed by the ancien regime in the form of public street lighting ${ }^{34}$. Moreover, the New York Draft Riot of 1863 is said to have prompted the deliberate destruction of gas lighting infrastructure by workers rebelling against Civil War conscription, resulting in localised blackouts ${ }^{35}$. A more centralised approach to the extinguishing of lights at night was needed during the Second World War, when enforced blackouts were designed to thwart enemy bombers during their night-time raids by helping to disrupt recognisable patterns of light-ondark from above, as part of wider regimes of civil camouflage ${ }^{36}$. In Britain, such city-wide blackouts are said to have contributed towards an unexpected increase in membership of the British Astronomical Association, as the night skies were opened up to the British people ${ }^{37}$. Furthermore, David Nye points out that 'military blackouts' were also used in the United States before and during the Second World War. This author goes on to explore 'the different social constructions of artificial darkness' in examining blackouts of many different causes and scales in the United States ${ }^{38}$. Nye understands these episodes in various ways, including 'as a crisis in the networked city, as the failure of an engineering system ... as a sudden encounter with sublimity, and as memory, aestheticized in photographs ${ }^{39}$. Here we can see how the absence of light has had a multitude of different meanings, from blackouts that induce panic to those that foster a benevolent sense of connection to the natural world.

Indeed, for some, the advent of public lighting has been associated with a romanticisation of the pre-modern night. Writing about pre-Victorian London, Sukhdev Sandhu has lamented how the onset of the night had 'brought back trace memories of an older London dense with eldritch forestry', and how, in contemporary times, the London night has been re-branded as 'London nightlife' and promoted as little more than an economic commodity ${ }^{40}$. Furthermore, the perceived loss of natural moonlight as a result of 'industrialised society's excessive use of artificial light' has inspired artist Katie Paterson to develop an installation consisting of a single lit bulb specifically designed to replicate the light of the full moon, along with a lifetime's supply of spare bulbs ${ }^{41}$. Such accounts echo similar types of protest against 'the shape and structures of the contemporary world [which] assert that humanity must renew its relationships with its past, the natural world and the spiritual realm'42, which in Britain has found expression through such means as the Romantic movement, fantasy literature and the post-war green movement. What these varied accounts have in common is that they complicate typical 'Enlightenment' narratives of progress that have contextualised the development of artificial lighting, and in doing so raise questions of protest, subversion and romanticism that speak to underlying issues about the place of industry, science and technology in the development of modern landscapes.

One way in which geographers have engaged with issues of modernity and landscape has been through what are termed moral geographies. Although concern with ethics and values has an established record in human geography, there has been a renewed interest in recent years, particularly when considering the notion of moral landscapes. Here, research has shown how 'local culture is closely implicated in the geography of everyday moralities ${ }^{\prime 4}$, with certain behaviours, representations and developments in specific settings being viewed and enacted through a lens of morality. As such, David Livingstone has examined 'climate's moral economy' in discourses of British 
imperialism in the $19^{\text {th }}$ and early- $20^{\text {th }}$ centuries. Livingstone identifies the ways in which certain climatic regions 'implied an ethnic moral topography' through which some of the exploitative processes of empire were justified ${ }^{44}$. As well as being played out across empires in this way, researchers have shown how morality has informed geographical practice in British intellectual history and in the development of certain types of planned landscape. As such, discourses of 'amelioration' and 'improvement' informed the development of social science in $19^{\text {th }}$ century England as a means of encouraging sanitation and urban environmental reform ${ }^{45}$, whilst country parks designed for landed gentry by the likes of Humphrey Repton and Lancelot 'Capability' Brown were said to incorporate models of social harmony and cultivate what Stephen Daniels has termed 'a morality of landscape ${ }^{\prime 46}$. Here, Repton is said to have 'appeal[ed] to landowners to intervene on behalf of an impoverished and disaffected labour force and thereby restore social harmony' ${ }^{47}$, which, ultimately, only contributed to 'the display of paternalism' ${ }^{48}$ rather than offering genuine progressive, moral landscapes. Applying comparable approaches to the interpretation of the English countryside in the inter-war period, David Matless has examined social practice in landscapes of open-air leisure. Here, Matless shows how 'behaviour appropriate to a particular urban habitat [is seen as] out of place in the English rural landscape ${ }^{\prime 49}$, bringing to bear a tension between what kind of behaviour is expected in urban and rural areas. National Parks are highlighted as a particular kind of space where moral codes of behaviour were expected, and, following their initial designation in 1940s Britain, they were promoted as 'national spiritual spaces' where people could re-assert their links to a more fundamental conception of nature and the $\operatorname{cosmos}^{50}$. Conversely, behaviour which contradicts this type of quiet reverence for the natural world was frowned upon as 'alien and vulgar' in environments such as the Norfolk Broads in the early- $20^{\text {th }}$ century ${ }^{51}$.

More recent studies on the geographies of illumination implicitly draw upon these moral geographies of landscape. Here, Tim Edensor and Steve Millington have shown how Christmas illuminations on residential properties in working-class urban areas of Britain have attracted opprobrium from the media and other neighbourhood inhabitants, raising debates about 'how nocturnal urban space should be appropriately regulated ${ }^{\prime 52}$. This moral geography of class and display highlights how not only the extent, but also the form of outdoor lighting comes into question, with 'modest, chic, white and blue lighting' gaining social credence over 'more colourful extravaganzas' in the eyes of middle-class homeowners ${ }^{53}$. Furthermore, we can see how the qualities of artificial light give rise to questions of place, and the ways in which light transgresses space, crossing physical and cultural boundaries. This has led to engagements with the affective qualities of night-time illumination and darkness ${ }^{54}$, which in turn can address issues concerning the experience of landscape. Here, amongst calls for further appreciation of the 'temporal patterning of life', including tidal rhythms and their associated agency ${ }^{55}$, geographers have started to understand darkened landscapes as sites of affective encounter. As such, Nina Morris has noted the ways in which 'being immersed in darkness engenders a different sense of self within the landscape ${ }^{56}$ in the context of an outdoor nocturnal art installation on the Isle of Skye in Scotland; whilst James Robinson has suggested that the night-time 'bomber body' over wartime Britain experienced the condition of darkness 'through tones, textures, forms and shapes that reveal themselves to the body-in-motion'57.

To summarise; researchers have offered valuable insights into the ways in which the development of artificial lighting has been connected ideologically to notions of enlightenment and progress in modern society. Against this, however, romantic associations of darkness have been identified 
alongside accounts of protest, disruption and subversion. As shall be demonstrated in this paper, these contrasting accounts, along with an understanding of moral landscapes, form the essential context in which geographies of light pollution and the motivations of the CfDS can be understood. This goes against assumptions that light pollution might simply constitute a problem that only affects amateur astronomers, thereby understanding debates about light pollution as debates about landscape. Furthermore, we have seen how geographies of light and darkness have presented ways of interpreting landscape that are inherently connected to both representational and affectual concerns, because of the notion of light/darkness as a visual medium, but also as a condition that engenders emotions and other sensorial engagements. Rather than prioritise one form of analysis over another, therefore, this paper will demonstrate how geographies of light and darkness can help to explore the covalent qualities of landscape as both a 'way of seeing' and also as a meaningful experience of place.

\section{Light Pollution and the Astronomical Sublime}

Since its launch in April 1990, the Hubble Space Telescope has helped to define a vision of outer space that has been referred to as the 'astronomical sublime'. Examining the Hubble collection, Elizabeth Kessler has identified a tendency for space photographs to emphasise 'saturated colours, high contrast, and rich detail as well as majestic compositions and dramatic lighting ${ }^{\prime 58}$ in images of vast cosmic agglomerations such as the Eagle Nebula, and compares such pictures to Romantic landscape photographs of the American West by the likes of Ansel Adams. Invocations of the astronomical sublime have been highlighted in a different context by Maria Lane, who, in her investigation of American astronomy in the early-20 th century, notes that 'the higher and more remote the observatory, the more sublime its conditions for scientific work ${ }^{\prime 59}$, referring not only to the mountainous landscape surroundings of some American observatories, but also the superior quality of the astronomical observations and recordings that resulted. These examples demonstrate how a sense of the sublime can relate to that which is set aloft or is seen as transcendent, and even extended beyond the realms of the Earth's atmosphere and gravitational attraction. But the sublime has also been connected to a more elusive experience which 'slips out of conventional understanding, [marking] the limits of reason and expression together with a sense of what might lie beyond these limits' ${ }^{\prime 60}$. Both interpretations of the sublime relate to the practise of amateur astronomy in its focus on imagery and the mysteries of the universe. This can be seen in contrast to the professional side of astronomy, which tends to be more concerned with the interpretation of data more commonly derived from outside of the visual spectrum such as gamma rays and infra-red radiation $^{61}$. The sense of the astronomical sublime is perhaps best articulated by nature writer Robert MacFarlane, whose book The Wild Places is quoted on the Campaign for Dark Skies website ${ }^{62}$, in which he describes looking up at the sky on a cloudless night in Cumbria in the north of England, whereby he experiences,

'a sudden flipped vertigo, the sensation that your feet might latch off from the Earth and that you might plummet upwards into space ${ }^{63}$.

An understanding of this interpretation of amateur astronomy, including what Edensor has called 'the affective power of the star-saturated sky' ${ }^{64}$ helps us to appreciate what is seen to be at risk in the campaign against light pollution, which in turn provides a window on a certain perception of how British landscapes should be seen and experienced. 
These affective relationships with dark sky landscapes, for amateur astronomers, are commonly connected to childhood memories of viewing the stars at night. In a memo circulated to the BAA Council meeting at which the CfDS originated, one member wrote of the 'childhood experience of a sight of the Milky Way on a clear Moonless night', and a 'spark of wonderment' at the realisation of the extent of the $\operatorname{cosmos}^{65}$. Stories of childhood experience also emerge when discussing early interest in astronomy, with one interviewee recalling at the age of seven, 'a very bright shooting star one night as we were coming home late in the summer' ${ }^{66}$, and another remembering the reassuring presence of the stars in the night sky after a wartime air raid ${ }^{67}$. Furthermore, astronomers are keen to relate their interest to children, through initiatives such as a mobile inflatable planetarium, which tours schools and youth groups across the country and is claimed to have held over 100,000 people in total ${ }^{68}$. In accordance, campaign groups such as the CPRE have lamented that 'many children have never seen the real Milky Way'69, in an argument that recalls peoples' own memories of childhood stargazing, and juxtaposes this against a perceived lack of experience for the children of today, and indeed the future, because of the impact of light pollution. As Hayden Lorimer has put it in a different context, 'the child's eye view becomes the measure of all things' ${ }^{70}$.

Invocations of childhood awe at the night sky often lead to associations with the Earth's history, moving from a generational time-scale to a geological temporal frame. Following this line of thought, connections with ancient peoples and landscapes have been invoked by anti-light-pollution campaigners, both upon questioning and as part of their campaign publications. As such, the natural cycle of night and day is said to connect with 'something quite primitive, quite innate in all of $\mathrm{us}^{\prime 71}$, whilst one might consider the 'starry vault which early hominids tried somehow to understand'72. Furthermore, this primeval wonder at the night sky is suggested to have helped form the basis for human cognition and the development of such characteristics that define humankind:

'For the last half a million years, people have looked up and seen this fantastic light above their heads [which has] inspired them to all sorts of thoughts and processes. It's turned us into poets, scientists, musicians, this amazing sight. ${ }^{73}$

Sometimes in the light pollution literature, this kind of language is presented alongside narratives of cosmological destruction, entropy and the far-reaching timeframe of the universe. Hence, whilst the atoms that comprise human beings are said to have been 'created in some distant and probably long-dead star', when the distant future brings about the death of the Solar System,

'whatever is left of our material selves ... will be redistributed, recycled, into the cosmic depths which we can no longer ... properly see or contemplate. ${ }^{74}$

A similar understanding of a 'heightened, cosmological sense of self' is discussed by Lorimer in researching the writings of British archaeologist Jaquetta Hawkes ${ }^{75}$. Her $A$ Land (1951) is said to connect human experience of landscape with a 'biological consciousness reaching all the way back to primitive life-forms existing in deep time ${ }^{76}$. This kind of writing, as found in light pollution literature, points towards an understanding of landscape that incorporates the night skies, which are said to represent 'half our environment', alongside the Earth's geological history, into a sublime understanding of humanity's place in the $\operatorname{cosmos}^{77}$. Hence, by placing the onset of light pollution in this context, and by emphasising the perceived importance of a cosmic backdrop to human existence, the campaign against light pollution seeks a route towards legitimacy and agency. 
The representation of ancient landscapes is therefore a technique that is commonly used by the light pollution lobby in its illustration of the issue at hand. One particular landscape feature that is frequently invoked is Stonehenge, a prehistoric monument in Wiltshire, southern England. Figure 1 shows a typical representation, whereby the ancient and mysterious monument is seen as threatened by the onset of light pollution in the surrounding area, in this case, skyglow.

Fig.1 - Stonehenge with light pollution. The online caption reads: 'the view from Stonehenge on Salisbury Plain towards Amesbury, $4 \mathrm{~km}$ away. Amesbury is not a big town - a perfect example of how light from even a minor population centre can travel at low angles to spoil the sky far away'

Reproduced under Creative Commons License: https://creativecommons.org/licenses/bync-sa/2.0/legalcode

Attributed to Grant Privett for the Campaign for Dark Skies.

Source: www.flickr.com/photos/campaignfordarkskies/4927021952/

Here, the view of Stonehenge is seen as tainted by a background skyglow effect of lurid orange. By examining the image further, we can see how it has been carefully composed in order to demonstrate the effect of light pollution. The most important element is probably the directional aspect, facing eastwards towards the nearby town of Amesbury and its light emissions. Weather conditions also contribute to the effect of skyglow, with an overcast night sky reflecting light more dramatically than the comparatively diffuse effects of atmospheric skyglow, whilst a relatively long exposure and flash are needed to highlight the background colour and pick out the stones themselves at night. This image, which appears on the CfDS website and in other promotional material, can be seen in contrast with a view of Stonehenge taken under different conditions (Fig. 2).

Fig. 2 - Stonehenge; Image Credit \& Copyright: Philip Perkins www.astrocruise.com

Also reproduced in CfDS promotional leaflet, Starry, Starry Night - Winning back the wonders of the night sky, (CfDS), p. 2, with the caption: 'Ancient skies over Stonehenge'

This photograph, taken by a CfDS supporter and reproduced in a Campaign leaflet, illustrates how ancient monuments such as Stonehenge should be viewed at night according to amateur astronomers or astrophotographers. It shows the passage of the Hale-Bopp comet in March 1997 against the constellations of Andromeda, Perseus and Cassiopeia, with the faint remnant light of the setting Sun casting the stones in silhouette, with, of course, no interference from skyglow. The passage of comets and meteors have long inspired landscape art, including a 1783 meteor which was depicted along its north-south passage by amateur and professional observers in Georgian Britain. Like such earlier images, this contemporary depiction seeks to document and register a celestial phenomenon, but it also reveals certain 'poetic and cartographic codes of landscape taste ${ }^{78}$. So, 
whilst the astronomical features of the night sky draw the viewer's attention above, a red light is also seen cast against the inner ring of the stones themselves, most likely added using postproduction image software. In a similar image by the same photographer, this lighting effect is said to 'provide an ambience of ancient times'79 whilst the CfDS caption, 'Ancient skies above Stonehenge', and the stones' theorised significance as an astronomical calendar, all combine to emphasise this notion of the astronomical sublime in the context of ancient landscapes, under threat from light pollution.

What draws together the themes in this section, summarily the experience of childhood awe and the representation of ancient landscapes, under this notion of the sublime, is a temporal imagination of the terrestrial and celestial environment that is seen as natural, enduring and harmonious. Conversely, excessive artificial light is seen as recent, irresponsible and unnatural. By setting the campaign against light pollution in this moral context, an evocative measure of the value of dark night skies is effectively wielded. As one campaigner put it,

'Seeing your own galaxy: what is the educational, philosophical value of something that wonderful? ... if you allow that to be spoiled, then you're losing quite a $\operatorname{lot}^{\prime 80}$.

\section{Light Pollution and the Threat of Urbanisation}

Having examined the construction of the astronomical sublime in light pollution debates, and its characterisation as something that needs protecting, it is appropriate to discuss one of the main forms of perceived threat to this romantic notion of landscape; urbanisation. As we have seen, the main ally of the CfDS has been the CPRE, whose role in campaigning against both light pollution and urbanisation provides the essential context for this argument ${ }^{81}$. According to an early member of the CfDS, the CPRE's involvement in anti-light-pollution campaigning initially developed out of an interest in 'preserving the night time environment' ${ }^{82}$, which included the protection of wildlife as part of the preservation of certain ideas of the countryside landscape. Accordingly, the effect that light pollution is reported to have on animals, particularly birds and invertebrates, is noted by the CfDS on their website and in other promotional material ${ }^{83}$. Although this kind of motivating factor aligns with the CPRE's current identity as an environmental charity ${ }^{84}$, their part in the campaign against light pollution also speaks to earlier characterisations of the CPRE, before the environmental movement of the late- $20^{\text {th }}$ century made an impact. Indeed, the CPRE was founded in 1926 by town planner Patrick Abercrombie as 'The Council for the Preservation of Rural England', and initially sought to campaign against urban sprawl, since defined as 'dispersed, low-density development on the edges of urban areas, characterised by fragmented and ribbon development ${ }^{\prime 85}$. In a current promotional leaflet on the history of the CPRE, the writing of J B Priestley is quoted to highlight the problems associated with urban sprawl in inter-war England, which was seen as in danger of becoming,

'the England of arterial and by-pass roads, of filling stations and factories that look like exhibition buildings, of giant cinemas and dance halls and cafes, bungalows with tiny garages, cocktail bars, Woolworths, motor coaches' ${ }^{86}$.

Matless has examined the CPRE and its adherents in this period, and has explained how 'a normative geography of distinct urbanity and rurality is asserted over an England-in-between of suburb, plotland and ribbon development', through what is termed 'a morality of settlement' ${ }^{87}$. Such fears 
highlight the moral codification of urbanisation, and draw attention to the spread of what Henri Lefebvre has called the 'urban fabric', and a realisation that the countryside can be seen increasingly as part of the town's 'environment' ${ }^{\prime 8}$. Hence, in its collaboration with the CPRE in the early-1990s, the CfDS implies that artificial light is a threat to rural areas, in the same way that the likes of bungalows and cocktail bars were for the CPRE in the inter-war period, drawing upon established, conservative notions of the rural as the English national heartland.

Moreover, key members of the CfDS are happy to accept the parallel between urbanisation and the spread of light pollution, with the resultant state of opinion being that light pollution 'threatens urban fringe and rural areas ${ }^{\prime 89}$ more than anywhere else. Referring to the 1980 s as a period when astronomers started to become aware of widespread light pollution, one campaigner identifies 'a slow spread ... outwards into what was originally a rural area' ${ }^{90}$, whilst another notes that light pollution has 'crept up ... slowly [and] insidiously' on the public ${ }^{91}$. This sense of malevolence was most alarmingly articulated in the previously-mentioned 1990 BAA Council meeting memo by the then Director of the Astrophotography section of the BAA. Here, light pollution is described as a 'sky cancer' which 'threatens to curtail virtually all observational astronomy in our country by the year $2000^{\prime 92}$. As such, the analogy suggests that light pollution would spread outwards, from certain infected areas (towns and cities) into healthy parts of the country, whose devastating effects on astronomical observation could result in the death of the BAA itself. As well as associating light pollution with urbanisation through this notion of an insidious spread, light pollution has prompted the CfDS to draw upon the separation between urban and rural as an ideal, and light pollution as a threat to this dichotomy, in much the same way that the CPRE in its early years sought to preserve an aesthetic distinction between town and country. Hence, is it claimed that light pollution 'urbanises places that are not urban', whilst places such as the South Downs National Park and the New Forest in southern England become sites of contestation, and are said to have 'an urban feel at night ... because of the spill of light' ${ }^{\prime 33}$. Again, light pollution is said to 'erase the distinction between town and country. It ceases to be rural if it's lit up' ${ }^{94}$.

Imagery has always been important to the CfDS in order to illustrate the problem of light pollution, which is natural given that amateur astronomy is, for the most part, a visual exercise. One of the most interesting and effective ways in which the Campaign drew attention to 'the growth of the problem'95 of light pollution was through commissioning a 'Dark Skies Map' of Britain, which combined the techniques of mapping and remote sensing to create a powerful propaganda tool. This was produced by the UK's National Remote Sensing Centre, and has been described as 'a mosaic of satellite images [taken] around midnight ${ }^{\prime 96}$, detecting the spatial variation of infra-red radiation emissions and representing this information visually, creating an authoritative and visually arresting view of Britain from above. The data was gathered mainly from the UK's Defence Meteorological Satellite Program, which was released to the academic and professional community after having been deemed as outside of any national security interest ${ }^{97}$. Once the map had been produced and given to the CfDS, it was turned into a poster and distributed by the Campaign ${ }^{98}$. By the mid-1990s, however, the amount and quality of satellite information available had increased dramatically, and the Campaign collaborated with Italian scientist Pierantonio Cinzano and colleagues, who produced a series of updated light pollution maps of Europe. These maps combined different types of data to show the extent to which stars in the night sky would be visible from the ground (See Fig.3). Related to this was a series of papers published in the Monthly Notices of the Royal Astronomical Society ${ }^{99}$, with the Campaign then being able to quote a 'reputable, refereed' journal article in articulating 
their arguments against light pollution ${ }^{100}$. This search for legitimacy is a familiar pattern within the activities of campaigns and societies ${ }^{101}$, and would have augmented the confidence of the CfDS at this time as they sought to spread their message of combating light pollution.

\section{Fig.3: Light pollution map of the British Isles}

Credit: P. Cinzano, F. Falchi (ISTIL- Light Pollution Science and Technology Institute), C. D. Elvidge (NOAA National Geophysical Data Center, Boulder). Copyright Royal Astronomical Society. Reproduced from the Monthly Notices of the RAS by permission of Blackwell Science. See P. Cinzano et al (2001)

Cinzano's images have since been used to produce the Philips Dark Skies Map of the UK, purporting to show 'the visibility of stars from any location in Britain and Ireland ... not just [light emitted] upwards towards a satellite'102. Updating the style of the NRSC's initial infra-red representation, this map overlays a brightly-coloured isobar representation of light pollution over a UK road map, with orange / red colouring indicating the most obscured night skies, and blue / black showing the clearest areas. As such, the Philips map promises the dual purpose of conventional navigation alongside specialised dark-sky selection to amateur astronomers as they travel to their viewing destinations around the British Isles. Whilst the earlier NRSC map only used one set of satellite data, the latest maps use a combination of ground-based and satellite-gathered information to produce a more 'accurate' representation of light pollution. This goes some way to taking into account the complicated mixture of light reflected downwards and sideways through the air that causes atmospheric light pollution, or skyglow, as we experience it from the ground. The use of maps as conveyors of authority and 'truth' is nothing new ${ }^{103}$, however the Dark Skies Maps produced by the CfDS and its allies provide an example of the extension of this authoritative vision by incorporating data gathered from Earth orbit. Indeed, the use of the satellite to act as an all-encompassing 'Apollo's Eye' ${ }^{104}$ is a relatively recent phenomenon that has been explored by researchers interested in the geographies of outer space and its associated retrospective gaze ${ }^{105}$, whilst its use by the CfDS represents the scientific side of the Campaign, and its willingness to adopt technological visions of the land from above, in addition to the more familiar register of landscape.

Although the Dark Skies Maps have increased in sophistication, it was not the scientific accuracy of the early light pollution maps that was necessarily important to the Campaign. Indeed, one early member described the initial map as 'incredibly useful [in providing people with] information in a way they can understand ${ }^{106}$, whilst explaining that,

'A satellite image on its own tells a story. The original image in 1990 was a dramatic thing when it appeared in all the papers. People were shocked by it I think. It was an amazing thing to have at that time so early in the campaign. ${ }^{107}$

Here, the 'story' of these satellite images is one of urbanisation, a narrative that is further augmented when chronological comparisons of light pollution maps are presented. Such comparisons are made by the CPRE in their 2003 promotional leaflet entitled Night Blight, which is presented with the sub-heading 'Rapidly spreading light pollution chases the stars from the night ... 
closing our window to the universe' ${ }^{108}$. Here, amid reports that 'orange and pink sky glow spreads further and further out from our towns and cities', light pollution maps are said to 'pick up some of the sky glow being cast out from well-lit areas into unlit countryside ${ }^{109}$. Further stressing the point that light pollution is spreading from urban to rural areas, national and regional light pollution maps from 1993 and 2000 are displayed side-by-side, which are claimed to 'expose a major growth in light pollution over just seven years ${ }^{\prime 110}$.

Whilst the threat of urbanising light pollution that is made clear by the CfDS and CPRE harks back to earlier protests against urban sprawl in the countryside, the steps that are advocated by both groups can be seen as forward-looking, not regressive. Anti-light-pollution campaigners are keen to point out that artificial light 'has brought great benefits' to society, whilst they are also wary of characterising themselves as 'eco-warriors' advocating 'militant action'111 and the widespread removal of artificial light. Indeed, from the outset, the CfDS has engaged with the lighting industry to improve standards and work towards the take-up of more efficient lighting. As such, a book written by one of the Campaign's committee members has been well-received by those in the lighting industry, to the extent that it is being published and sold by the Institute of Lighting Professionals as part of their collection of recommended publications ${ }^{112}$. Furthermore, the Campaign has embraced contemporary issues that surround the light pollution debate in Britain, becoming more than just a lobby group for astronomers, and more of an environmental campaign group. As stated by a leading member of the Campaign;

'The two massive factors in lighting at the moment are the energy crisis ... and, secondly, remote control'113

Here, two factors that exist in the wider economy are harnessed by the light pollution lobby in order to further their goals, as well as those of the lighting industry. Given the recent financial crisis and the concurrent need to address energy efficiency in view of the 2008 Climate Change Act, which requires the UK to reduce its carbon emissions by law, a reduction in energy waste through improved lighting is an argument that the Campaign has found to have traction. At the same time, advances in lighting technology have seen the adoption of LED lighting as a potential solution to the compounded problems of light pollution and energy inefficiency. Hence, what is referred to as the 'era of thick lighting' ${ }^{\prime 14}$, whereby public lights are turned on and off at fixed times each day, has the potential to be replaced by a regime of fully-controllable LED lighting, whose operation is responsive to levels of traffic, time of day and other variables. In this way, we can see how the light pollution lobby has incorporated a wide range of attitudes towards the representation and advocacy of the night time countryside. Whilst urbanisation and light pollution are conflated in what can at first be seen as a fairly backward-looking and reactionary manner, the use of satellite imagery and the promotion of modern, energy-efficient lighting points towards a future for the British countryside that incorporates modern elements whilst seeking to preserve a traditional separation between town and country.

\section{Conclusions}

This article has argued for a moral geographical interpretation of light pollution by focusing on the activities of the Campaign for Dark Skies, a branch of the British Astronomical Association that has forged links with other groups including the influential CPRE. In doing this, some of the cultural and historical geographies of light pollution have been set in place. It has been established that this 
Campaign was the first co-ordinated effort to combat light pollution in the UK, which is said to have increased sharply during the mid- to late-1980s. Examining this Campaign through a geographical lens, informed by ideas of moral landscapes and the place of light and dark in modern society, two principal characteristics have been identified. Firstly, the Campaign has drawn upon romanticism and a notion of the astronomical sublime in order to articulate what is placed under threat by the onset of light pollution. In doing this, an understanding of landscape that incorporates aspects of cosmology, as well as generational and geological timeframes, has been noted. Second, a correlation has been drawn between the perceived spread of light pollution and the idea of urbanisation. Hence, light pollution is seen to threaten rural areas, which are in turn characterised as intrinsically dark spaces at night. By doing this, the light pollution lobby has drawn on conceptions of Englishness that were originally deployed by the CPRE in its earlier campaign against urban sprawl in the mid$20^{\text {th }}$ century, implying that by preserving the dark landscapes of Britain, the national rural heartland is also protected. As part of this preservationist attitude, the Campaign has also shown that it is in step with current technological developments, with the future of lighting in the UK seen as controlled, efficient, and appropriate to a sense of place. Furthermore, we have seen how contributions to the geographies of light and darkness can unite different ways of thinking about landscape, through exploiting both the visual and the experiential qualities of light and darkness. Thereby, in understanding the affective qualities of sublime interpretations of the cosmos, alongside visual representations of light pollution, we can begin to understand landscape through a combination of lived experience, memory, aesthetics and imagery.

\section{Reference List}

\footnotetext{
${ }^{1}$ B. Mizon, Light Pollution: Responses and Remedies (London: Springer, 2002), p. 34

2 L. Claudio, 'Switch on the Night - Policies for Smarter Lighting', Environmental Health Perspectives, 117, 2009, p. 29

${ }^{3}$ R. Chepesnik, 'Missing the Dark - Health Effects of Light Pollution', Environmental Health Perspectives, 117, 2009, p. 21

${ }^{4}$ Mizon, Light Pollution, pp. 28-9

${ }^{5}$ Introduction, in Blinded by the Light? A handbook on light pollution (Hampshire: BAA, 2009), p. 4

${ }^{6}$ The term pollution in itself carries a further moralistic meaning from before its association with the modern environmental movement, incorporating notions of 'desecration ... spiritual or moral impurity' ['Pollution, n.', OED Online (Oxford University Press, December 2013) http://www.oed.com/view/Entry/146992 - accessed February 23, 2014]

${ }^{7}$ K. M. D. Lane, 'Geographers of Mars: Cartographic Inscription and Exploration Narrative in Late Victorian Representations of the Red Planet', Isis, 96, 2005, p. 480

${ }^{8}$ The concept of environmental pollution was, of course, not new at this time, with the rise of industrialisation prompting some of the first instances of environmental legislation in the UK by the mid-19th century. [See E. Ashby and M. Anderson, The Politics of Clean Air (Oxford: Oxford University Press, 1981)]

${ }^{9}$ Interview 1: A leading member of the CfDS, $6 / 3 / 13$

${ }^{10}$ BAA Council minutes, 28/2/90 (British Astronomical Association, Burlington House, London)

${ }^{11}$ BAA Council minutes, 28/2/90 (British Astronomical Association, Burlington House, London)

12 Interview 1

${ }^{13}$ CfDS, Starry, Starry Night - Winning back the wonders of the night sky (Hampshire: BAA, 2007)

${ }^{14}$ Chepesnik, 'Missing the Dark'; Claudio, 'Switch on the Night'

${ }^{15}$ S. Lockley, 'Human health implications of light pollution', in Blinded by the Light? A handbook on light pollution (Hampshire: BAA, 2009), pp. 21 - 25
} 
${ }^{16} \mathrm{G}$. Cliff and C. Henshaw, 'The (sometimes hidden) adverse environmental effects of light pollution', in Blinded by the Light? A handbook on light pollution (London: BAA, 2009), pp. 9 - 13

${ }^{17}$ Interview 2: A leading member of the CfDS, 1/7/13

18 Interview 1

${ }^{19}$ Over two dozen Dark Sky Places have so far been designated around the world (www.darksky.org). In the UK, the latest of these to date has been Northumberland National Park, which was assigned the status of Dark Sky Park in December 2013.

${ }^{20}$ The interviewees' names and precise roles in the Campaign have been removed from this paper to protect their privacy.

${ }^{21}$ W. Schivelbusch, Disenchanted Night: The Industrialisation of Light in the Nineteenth Century (Oxford, Berg, 1988) p. 4

${ }^{22}$ Schivelbusch, Disenchanted Night, p. 6

${ }^{23}$ C. Koslofsky, Evening's Empire: A History of the Night in Early Modern Europe (Cambridge: Cambridge University Press, 2011)

${ }^{24}$ P. Baldwin, 'In the Heart of Darkness - Blackouts and the Social Geography of Lighting in the Gaslight Era', Journal of Urban History, 30, 2004, pp. 749 - 768; J. A. Jackle, City Lights - Illuminating the American Night (Baltimore: John Hopkins University Press, 2001)

${ }^{25}$ Schivelbusch, Disenchanted Night

${ }^{26}$ A. Barnaby, 'In the Night Garden: The Dark Walk at Vauxhall Pleasure Gardens, London', Association of American Geographers Annual Meeting, Los Angeles, 12 April 2013

${ }^{27}$ C. Otter, The Victorian Eye - A Political History of Light and Vision in Britain, 1800 - 1910 (London: University of Chicago Press, 2008)

${ }^{28}$ Schivelbusch, Disenchanted Night, p. 71

${ }^{29}$ Otter, The Victorian Eye, p. 65

${ }^{30}$ Baldwin, 'In the Heart of Darkness', p. 755

${ }^{31} \mathrm{~T}$. Edensor, 'Reconnecting with darkness: gloomy landscapes, lightless places', Social and Cultural Geography, 14, 2013, p. 3

${ }^{32}$ F. Driver, Geography Militant - Cultures of Exploration and Empire (Oxford: Blackwell, 2001); J. Ryan, Picturing Empire - Photography and the Visualisation of the British Empire (London: University of Chicago Press, 1999)

${ }^{33}$ Enlightenment rhetoric should be seen in the broader context of non-Western traditions of light and dark. One example of this is Junichiro Tanazaki's (1933) In Praise of Shadows, which explores the significance of darkness in Japanese culture.

${ }^{34}$ Schivelbusch, Disenchanted Night

${ }^{35}$ Baldwin, 'In the Heart of Darkness', p. 758

${ }^{36} \mathrm{~J}$. P. Robinson, "'Darkened surfaces": camouflage and the nocturnal observation of Britain, 194145', Environment and Planning A, 45, 2013, pp. 1053 - 1069

${ }^{37}$ R. McKinn, The History of the BAA - The First Fifty Years (London: BAA, 1990)

${ }^{38} \mathrm{D}$. Nye, When the Lights Went Out - A History of Blackouts in America (Massachusetts: MIT Press, 2010), p. 2

${ }^{39}$ Nye, When the Lights Went Out, p. 2

${ }^{40}$ S. Sandhu, Night Haunts - A Journey through the London Night, (London: Verso, 2010), pp. 10-12

${ }^{41}$ Hayward Gallery, Light Show Exhibition Guide, January - April 2013, London; K. Paterson, Light bulb to simulate moonlight, 2008

${ }^{42}$ M. Veldman, Fantasy, the Bomb and the Greening of Britain - Romantic Protest, 1945 - 1980 (Cambridge: Cambridge University Press, 1994), p. 39

${ }^{43}$ D. M. Smith, Moral Geographies - Ethics in a World of Difference (Edinburgh: Edinburgh University Press, 2000), p. 5

${ }^{44}$ D. N. Livingstone, The Geographical Tradition (London: Blackwell, 1992), p. 221

${ }^{45}$ Driver, 'Moral geographies' 
${ }^{46}$ S. Daniels, 'Humphrey Repton and the morality of landscape', in J. Gold and J. Burgess (eds.), Valued Environments (London: Allen and Unwin, 1982)

${ }^{47}$ Daniels, 'Humphrey Repton and the morality of landscape', p. 131

${ }^{48}$ Daniels, 'Humphrey Repton and the morality of landscape', p.137 (emphasis added)

${ }^{49}$ D. Matless, 'Moral Geographies of English Landscape', Landscape Research, 22, 1997, pp. 141 - 155

${ }^{50}$ Matless, 'Moral Geographies of English Landscape', p. 151

${ }^{51}$ Matless, 'Moral Geographies of English Landscape', p. 131

${ }^{52} \mathrm{~T}$. Edensor and S. Millington, 'Illuminations, class identities and the contested landscapes of

Chritsmas', Sociology, 43, 2009, p. 108

${ }^{53}$ Edensor and Millington, 'Illuminations', p. 104

${ }^{54} \mathrm{~T}$. Edensor, 'Illuminated atmospheres: anticipating and reproducing the flow of affective

experience in Blackpool', Environment and Planning D: Society and Space, 30, 2012, pp. 1103 - 1122;

Edensor, 'Reconnecting with darkness'

${ }^{55}$ O. Jones, 'The Breath of the Moon - The Rhythmic and Affective Time-spaces of UK Tides', in T.

Edensor (ed.) Geographies of Rhythm (Surrey: Ashgate, 2010), p. 193

${ }^{56} \mathrm{~N}$. Morris, 'Night walking: darkness and sensory perception in a night-time landscape installation', cultural geographies, 18, 2011, p. 335

${ }^{57}$ Robinson, 'Darkened Surfaces', p. 1056

${ }^{58} \mathrm{E}$. A. Kessler, Picturing the Cosmos - Hubble Space Telescope images and the astronomical sublime (London: University of Minnesota Press, 2012), p. 4

${ }^{59}$ K. M. D. Lane, 'Astronomers at Altitude - Mountain Geography and the Cultivation of Scientific Legitimacy', in D. Cosgrove and V. Della Dora (eds.) High Places - Cultural Geographies of Mountains, Ice and Science (London: I B Tauris, 2008) p. 136

${ }^{60}$ P. Shaw, The Sublime (London: Routledge, 2006), p. 2

${ }^{61}$ M. Hoskin, and D. Dewhurst, 'The Message of Starlight: The Rise of Astrophysics', in M. Hoskin (ed.) The Cambridge Concise History of Astronomy, (Cambridge: Cambridge University Press, 1999), pp. $219-305$

${ }^{62}$ www.britastro.org/dark-skies/ - web site accessed on 2/10/13

${ }^{63}$ R. Macfarlane, The Wild Places (London: Granta, 2007) p. 202

${ }^{64}$ Edensor, 'Reconnecting with darkness', p. 3

${ }^{65}$ Memoranda: Ron Arbour, 1990 (BAA Minute book, British Astronomical Association, Burlington House, London)

${ }^{66}$ Interview 2

${ }^{67}$ Interview 3: A former leading member of the CfDS, 4/6/13

${ }^{68}$ Interview 1

${ }^{69}$ CPRE, Night Blight (London: CPRE, 2003), p. 5

${ }^{70} \mathrm{H}$. Lorimer, 'Memoirs for the Earth: Jacquetta Hawkes's literary experiments in deep time', cultural geographies, 19, 2012, p. 92

${ }^{71}$ Interview 2

${ }^{72}$ Mizon, Light Pollution, p. 8

${ }^{73}$ Interview 1

${ }^{74} \mathrm{~B}$. Mizon, 'The night sky and wasted light', in Blinded by the Light? A handbook on light pollution (London: BAA, 2009), pp. 9 - 10

${ }^{75}$ Lorimer, 'Memoirs for the Earth', p. 88

${ }^{76}$ Lorimer, 'Memoirs for the Earth', p. 95

77 Interview 1

${ }^{78}$ S. Daniels, 'Great Balls of Fire - Envisioning the brilliant meteor of 1783', in S. Daniels, D. DeLyser, J. Entrekin and D. Richardson, Envisioning Landscapes, Making Worlds - Geography and the Humanities (London: Routledge, 2011), p. 155

${ }^{79}$ www.astrocruise.com - web site accessed on $2 / 10 / 13$ 
${ }^{80}$ Interview 1

${ }^{81}$ The Campaign to Protect Rural Wales and the Association for the Protection of Rural Scotland have also aligned themselves with the light pollution lobby. However, the CPRE's role in setting up the CfDS necessitates its primacy in this discussion.

82 Interview 2

${ }^{83}$ Cliff and Henshaw, 'Adverse environmental impacts of light pollution'

${ }^{84}$ www.cpre.org.uk/about-us/our-vision - web site accessed on 2/10/13

${ }^{85}$ E. McCann, 'Sprawl', in D. Gregory, R. Johnston, G. Pratt, M. Watts, and S. Whatmore (eds.),

Dictionary of Human Geography, $5^{\text {th }}$ Edn (Oxford: Wiley-Blackwell, 2009), p. 719

${ }^{86}$ CPRE, 2006

87 D. Matless, Landscape and Englishness (London: Reaktion: 1998), p. 32

${ }^{88} \mathrm{H}$. Lefebvre, The Urban Revolution (London: University of Minnesota Press: 2003 [1970]), p.4, 11

${ }^{89}$ Interview 2

${ }^{90}$ Interview 2

${ }^{91}$ Interview 1

${ }^{92}$ Memoranda: Ron Arbour, 1990 (BAA Minute book, British Astronomical Association, Burlington House, London)

${ }^{93}$ Interview 1

${ }^{94}$ Interview 1

${ }^{95}$ Mizon, 'The night sky and wasted light', p. 6

${ }^{96}$ Interview 2

${ }^{97}$ Interview 2

98 Interview 1

${ }^{99}$ P. Cinzano, F. Falchi, C. D. Elvidge, 'The first world atlas of the artificial night sky brightness', Monthly Notices of the Royal Astronomical Society, 328, 2001, pp. 689 - 707

100 Interview 2

${ }^{101}$ O. Dunnett, 'Patrick Moore, Arthur C Clarke and "British Outer Space" in the mid-20 ${ }^{\text {th }}$ century', cultural geographies, 19, 2012, pp. 505 - 522

102 Phillips Dark Skies Map, 2004

${ }^{103}$ See, for example, J. B. Harley, 'Deconstructing the Map', in T. Barnes and J. Duncan, Writing Worlds: Discourse, text and metaphor in the representation of landscape (Routledge: London, 1991), pp. $231-247$

${ }^{104}$ D. Cosgrove, Apollo's Eye: A Cartographic Genealogy of the Earth in the Western Imagination (Baltimore: John Hopkins University Press, 2001)

${ }^{105}$ F. MacDonald, 'Anti-Astropolitik: Outer Space and the Orbit of Geography', Progress in Human Geography, 31, 2007, pp. 592-615; Dunnett, 'British Outer Space'

${ }^{106}$ Interview 2

107 Interview 2

${ }^{108}$ CPRE, Night Blight, p.1

${ }^{109}$ CPRE, Night Blight, p.5, 6

${ }^{110}$ CPRE, Night Blight, p.7

${ }^{111}$ Mizon, 'The night sky and wasted light', p.5

${ }^{112}$ C. Badderley, Towards Understanding Skyglow (Rugby: Institute of Lighting Engineers, 2007)

113 Interview 1

114 Interview 1 